\title{
RECOVERY FROM AIRLINES UNDER THE DEATH ON THE HIGH SEAS ACT: A CONFLICTS RULE SUGGESTED*
}

Trie federal Death on the High Seas Act (DHSA), originally passed to provide a remedy for wrongful death aboard ships, ${ }^{1}$ generates problems through its judicial extension to aircraft falling into international waters. ${ }^{2}$ The principal difficulties center about proper interpretations of two sections of the act conferring separate grounds for suit in admiralty. Section one authorizes a decedent's representative to bring an action for the benefit of dependent relatives suffering pecuniary loss from wrongful death on the high seas. ${ }^{3}$ Section

*Fernandez v. Linea Aeropostal Venezolana, 156 F. Supp. 94 (S.D.N.Y. 1.957).

1. 41 Stat. 537 (1920), 46 U.S.C. $\S \S 761-67$ (1952). Relevant portions of the act are quoted notes 3-4 infra.

Transoceanic flights were virtually unknown when the act was passed (Lindbergh's crossing did not take place until 1927), and its legislative history does not indicate that Congress contemplated its extension to airplanes. See S. REP. No. 216, 66th Cong., 1st Sess. (1919) ; 59 Cong. Rec. 4482-86 (1920) ; Comment, 55 Colum. L. Rev. 907, 916, 920 (1955). But cf. Choy v. Pan-Am. Airways Co., 1941 Am. Mar. Cas. 483, 485 (S.D.N.Y.).

Unlike other major seagoing nations which permitted suits against the ships for wrongful death, American admiralty courts, following common-law doctrine, recognized no cause of action for wrongful death against American vessels in the absence of statutory authorization. The Harrisburg, 119 U.S. 199 (1886); Whitelock, A New Development in the Application of Extra-territorial Law to Extra-territorial Marine Law, 22 HARv. L. REv. 403, 408-09 (1909). Hence, prior to the DHSA, suits for wrongful death on the high seas against American vessels had to be based upon rights created by the state in which the shipowner resided. See, e.g., The Hamilton, 207 U.S. 398 (1907) (death due to collision between vessels owned by Delaware corporations governed by Delaware death statute); The E. B. Ward, Jr., 17 Fed. 456 (C.C.E.D. La. 1883) (death aboard a Swedish vessel as result of collision with an American ship governed by the death statute of the state in which the American shipowner resided).

A cause of action based upon a state's death statute was subject to any limitation contained therein. See, e.g., The Harrisburg, supra (statutory period of limitation); Quinette v. Bisso, 136 Fed. 825 (5th Cir. 1905) (amount of damages) ; Dorbin v. Mallory S.S. Co., 298 Fed. 349 (E.D.N.Y. 1924) (standing to sue). See also Magruder \& Grout, Wrongful Death Within the Admiralty Jurisdiction, 35 Yale L.J. 395, 397-98, 416 (1926).

The DHSA was passed to provide uniform treatment of wrongful death on American ships. For the history of the act, see Wilson v. Transocean Airlines, 121 F. Supp. 85, 89 (N.D. Cal. 1954) ; Hughes, Death Actions in Admiralty, 31 Y ALE L.J. 115, 117-19 (1921).

2. The DHSA has been extended to aircraft in the following jurisdictions: Higa $v$. Transocean Airlines, 124 F. Supp. 13 (D. Hawaii 1954), aff'd, 230 F.2d 780 (9th Cir. 1955), cert. dismissed, 352 U.S. 802 (1956); Wilson v. Transocean Airlines, supra note 1; Sierra v. Pan Am. World Airways, Inc., 107 F. Supp. 519 (D.P.R. 1952) ; Lacey v. L. W. Wiggins Airways, Inc., 95 F. Supp. 916 (D. Mass. 1951) ; Choy v. Pan-Am. Airways Co., supra note 1; Wyman v. Pan Am. Airways, Inc., 181 Misc. 963, 43 N.Y.S.2d 420 (Sup. Ct. 1943), aff'd without opinion, 267 App. Div. 947, 48 N.Y.S.2d 459 (1st Dep't), aff'd without opinion, 293 N.Y. 878, 59 N.E.2d 785 (1944), cert. denied, 324 U.S. 882 (1945).

3. Sections 1 and 2 of the DHSA, 41 Stat. 537 (1920), 46 U.S.C. $\S \S 761,762$ (1952), read:

"That whenever the death of a person shall be caused by wrongful act, neglect, or 
four, on the other hand, creates no cause of action but permits federal courts to enforce rights accruing under foreign law on account of death at sea. ${ }^{4}$ Whenever the DHSA is invoked, therefore, courts must determine whether standing to sue derives from section one or from the statute of another nation by way of section four. This determination of applicable law will necessarily control the amount of recoverable damages in so far as domestic and foreign legis-

default occurring on the high seas beyond a marine league from the shore of any State, or the District of Columbia, or the Territories or dependencies of the United States, the personal representative of the decedent may maintain a suit for damages in the district courts of the United States, in admiralty, for the exclusive benefit of the decedent's wife, husband, parent, child, or dependent relative against the vessel, person, or corporation which would have been liable if death had not ensued.

"SEC. 2. That the recovery in such suit shall be a fair and just compensation for the pecuniary loss sustained by the persons for whose benefit the suit is brought and shall be apportioned among them by the court in proportion to the loss they may severally have suffered by reason of the death of the person by whose representative the suit is brought."

Despite a last minute amendment contained in $\S 7$ that "the provisions of any State statutes giving or regulating rights of action or remedies for death shall not be affected by this Act . . ." 41. STAT. 538 (1920), 46 U.S.C. $\$ 767$ (1952), \$ 1 has been held to preempt state law. See, e.g., Middleton v. Luckenbach S.S. Co., 70 F.2d 326 (2d Cir. 1934); Wilson v. Transocean Airlines, 121 F. Supp. 85 (N.D. Cal. 1954); Batkiewicz v. Seas Shipping Co., 53 F. Supp. 802 (S.D.N.Y. 1943) ; Elliott v. Steinfeldt, 254 App. Div. 739, 4 N.Y.S.2d 9 (2d Dep't 1938). But see Higa v. Transocean Airlines, 230 F.2d 780, 782-83 (9th Cir. 1955), cert. dismissed, 352 U.S. 802 (1956) (dictum; $\S 7$ preserves the operation of state death statutes). See also Magruder \& Grout, supra note 1, at 420-23; Comment, 55 Colux. I. Rev. 907, 909-10 (1955).

The weight of precedent indicates that suits under $\$ 1$ must be brought in admiralty. See, e.g., Turner v. Wilson Line, Inc., 242 F.2d 414 (1st Cir. 1957) ; Wilson v. Transocean Airlines, supra. Conflicting decisions in the district courts of the Second Circuit seem to be finally settled in favor of exclusive admiralty jurisdiction. See Noel v. Linea Aeropostal Venezolana, 247 F.2d 677 (2d Cir.), cert. denied, 355 U.S. 907 (1957). See also Higa v. Transocean Airlines, supra (exclusive admiralty jurisdiction if no cause of action under state death statute). But see Sierra v. Pan Am. World Airways, Inc., supra note 2 (concurrent jurisdiction on nonadmiralty side of federal court); Elliott v. Steinfeldt, supra (state court concurrent jurisdiction); Wyman v. Pan Am. Airways, Inc., supra note 2 (same).

The extension of admiralty jurisoiction to wrongful death in airspace may also raise the constitutional problem of depriving claimants of their right to a jury trial. See Noel v. Linea Aeropastal Venezolana, supra (dictum) ; Comment, 55 Colum. L. Rev. 907, 91016 (1955). But see Comment, 41 Cornell L.Q. 243, 248-50 (1956).

4. Section 4 reads: "That whenever a right of action is granted by the law of any foreign State on account of death by wrongful act, neglect, or default occurring upon the high seas, such right may be maintained in an appropriate action in admiralty in the courts of the United States without abatement in respect to the amount for which recovery is authorized, any statute of the United States to the contrary notwithstanding." 41 STAr. 537 (1920), 46 U.S.C. $\$ 764$ (1952).

Section 4 codified the American court practice of enforcing causes of action for wrongful death granted by the law of the flag. See, e.g., La Bourgogne, 210 U.S. 95 (190S); The Sagamore, 247 Fed. 743 (1st Cir. 1917). See also S. Rep. No. 216, 66th Cong., 1st Sess. (1919); Comment, 41 Cornelr L.Q. 243, 250-51 (1956) (suits under $\$ 4$ may be brought at law, but the "without abatement" provision of this section is then inapplicable). 
lation afford dissimilar measures of relief. 5 The disparity between section one and section four recovery is not uniform, however, but can differ markedly depending upon whether an airline or a shipowner is being sued.

Construing the act in suits against shipowners, courts have preserved the traditional view that the tort law of the ship's flag establishes responsibility for wrongful death. ${ }^{\mathfrak{c}}$ Thus, section one embraces claims arising on American vessels, ${ }^{7}$ while section four is applied exclusively to all actions originating under other flags. ${ }^{8}$ This rule can result in larger recoveries from alien than from equally culpable American respondents because of the effect given laws

5. See note 20 infra.

6. For the traditional view, see, e.g., The Titanic, 233 U.S. 718, 732 (1914) ; La Bourgogne, 210 U.S. 95, 138 (1908); see also Restatement, Conflict of Laws $\$ 406$ (1934) (hereinafter cited as Restatenient, Conflicts); Higgrns \& Colomiros, International LAW OF THE SEA 39-54 (3d ed. 1954).

One important exception to the doctrine that the law of the flag applies to torts occurring on the high seas is found in judicial willingness to extend American law to an American-owned ship flying a flag of convenience. E.g., Gerradin v. United Fruit Co., 60 F.2d 927 (2d Cir. 1932) (suit by American seaman injured aboard American-owned vessel registered in Honduras); Zielinski v. Empresa Hondurena de Vapores, 113 F. Supp. 93 (S.D.N.Y. 1953) (same; injury in foreign waters) ; Torgersen v. Hutton, 243 App. Div. 31, 276 N.Y.S. 348 (2d Dep't 1934), aff'd, 267 N.Y. 535, 196 N.E. 566, cert. dentied, 296 U.S. 602 (1935) (same; half American ownership, foreign seaman injured in American waters). Citing Gerradin, the Supreme Court in Lauritzen v. Larsen, 345 U.S. 571, 587-88 \& n.24 (1953), discussed note 36 infra and accompanying text, indicated that ownership is a contact to be considered for choice of law in admiralty, although the case did not decide whether the law of the vessel's owner will apply when a foreign owner flies a flag of convenience. See Gulmore \& Black, Admiralty 388 (1957) (hereinafter cited as GiLnIORE \& BLACK). However, in Markakis v. Liberian S/S The Mparmpa Christos, $161 \mathrm{~F}$. Supp. 487 (S.D.N.Y. 1958), the court applied the Liberian flag of convenience to a Greek seaman injured in American waters aboard a ship owned by a Panamanian paper-company whose real owner was a Greek national. The court further held that use of American corporations as agents to obtain charters for the vessel, husband it and handle the crew's wages and claims, did not justify application of American law. Id. at 489, 505 .

Another exception to the general rule that tort recoveries are governed by the law of the flag may arise when two ships fying different flags collide on the high seas. See note $S$ infra.

7. See, c.g., Petition of Southern S.S. Co., 135 F. Supp. 358 (D. Del. 1955); Lawson v. United States, SS F. Supp. 706 (S.D.N.Y. 1950), modified on other grounds, 192 F.2d 479 (2d Cir. 1951), cert. denicd, 343 U.S. 904 (1952); The City of Rome, 48 F.2d 333 (S.D.N.Y. 1930).

8. The Vulcania, 41 F. Supp. 849 (S.D.N.Y. 1941) (suit for death aboard a foreign ship cannot be brought under $\S 1$, but only under § 4); The Vestris, 53 F.2d 847 (S.D. N.Y. 1931) (same).

If death occurs on an American-owned vessel flying a foreign "flag of convenience," cf. Lauritzen v. Larsen, 345 U.S. 571, 587 (1953), either the American-oriented $\S 1$ or the foreign-oriented $\S 4$ might conceivably apply. No flag of convenience cases have as yet arisen under the DHSA, but in analogous cases involving injuries to seamen aboard American-owned ships of foreign registry, American courts have been willing to apply the federal Jones Act, 41 STAT. 1007 (1920), 46 U.S.C. $\$ 688$ (1952). See note 6 supra. However, in Jones Act cases, "piercing the flag" acts to the shipowner's detriment since the injured seaman's tort recovery is based on American standards and is usually far greater than recoveries for comparable injuries in foreign jurisdictions. But if federal courts 
permitting shipowners to limit their liability. Foreign limitation statutes are termed "procedural" and refused recognition in United States courts." And the DHSA expressly forbids invocation of the American Limitation of Vessel Owner's Liability Act by persons sued for wrongful death under section four. ${ }^{10}$

choose to go behind the flag in $\S 1$ cases, the shipowner will benefit under the limitation of liability provisions inapplicable under $\$ 4$. See note 4 supra.

The cases are in conflict, however, when death results from collision between ships of diverse flags. The conflict stems from two Supreme Court decisions prior to the DHSA. The Scotland, 105 U.S. 24, 29-30 (1881), applied the American statute allowing limitation of shipowner liability to claims arising out of a collision between two foreign ships on the ground that, while the law of the flag will be applied to collisions between ships of the same nation, American law will govern a collision between vessels flying different colors. On the other hand, in La Bourgogne, 210 U.S. 95, 138 (1908), the Court looked to the law of the carrying ship when death resulted from a collision between ships of diverse foreign registry. At the time, however, the United States had no wrongful death statute. See note 1 supra.

The Titanic, 233 U.S. 718 (1914), seems to undermine The Scotland rationale by holding that $\S 3$ of the American Limitation of Vessel Owner's Liability Act, 9 Stat. 635 (1851), as amended, 46 U.S.C. $\$ 183$ (1952), is procedural and hence inapplicable even to a single foreign ship. Nevertheless, The Scotland was extended to the DHSA. See The Buenos Aires, 5 F.2d 425 (2d Cir. 1924) ( 1 embraces suits against Spanish ship that collided with an American vessel, causing death of an American seaman); The Presidente Wilson, 30 F.2d 466 (D. Mass. 1929) (same; American and Italian ships). But see The Aquitania, 1924 Am. Mar. Cas. 1440 (S.D.N.Y.) (applying the law of the foreign noncarrying vessel to death of Americans aboard an American ship); The Sagamore, 247 Fed. 743 (1st Cir. 1917) (same; prior to DHSA).

Although Restatement, Conflicts $\$ 410$ follows The Scotland, this rule has been widely criticized. See Hancock, Torts In the Conflict of Laws 273-80 (1942) ; RoBINson, Admiralty 828-39 (1939); Hughes, supra note 1, at 121-22; Magruder \& Grout, supra note 1 , at $41.1-16,423-26$.

9. The Titanic, supra note 8, at 732-33 (American rather than British limitation of liability statute applies to British ship sued in American courts; limitation of shipowner liability "clearly limits the remedy ... in cases where it has nothing to say about the rights") ; The Mandu, 102 F.2d 459, 463 (2d Cir. 1939) (limitation of liability in maritime cases related to remedy; law of the forum controls). Dictum in Black Diamond S.S. Corp. v. Robert Stewart \& Sons, Ltd., 336 U.S. 386, 395-96 (1949), implies that Titanic did not foreclose the possibility of federal courts enforcing foreign limitation of liability statutes. But the dictum has not been followed. Kloeckner Reederei \& Kohlenhandel v. A/S Hakedal, 210 F.2d 754, 757 (2d Cir. 1954) (The Titanic settled the question whether limitation of shipowner's liability is procedural and nothing in Black Diamond qualifies this). See also Restatement, Conflicts $\$ 411$ (law of the forum governs owner's ability to limit liability) ; Gilarore \& Black 736-40 (same); Comment, 31 Texas L. Rev. 889, 895 (1953) (limitation of shipowner's liability ought to be considered substantive).

On the "arbitrary" and illogical distinction between substance and procedure in conflict of laws, see 2 Harper \& Janes, Torts 1683 (1956).

10. 41 Stat. 537 (1920), 46 U.S.C. \$ 764 (1952), quoted note 4 supra; The Vestris, 53 F.2d 847 (S.D.N.Y. 1931).

The Limitation of Vessel Owner's Liability Act, 9 Stat. 635 (1851), as amended, 46 U.S.C. $\$ 183$ (1952), allows a shipowner to limit his liability for loss of life and property if loss occurred without his "privity or knowledge." When limitation is allowed, the maximum liability is the owner's interest at the end of the voyage in question. If this is insufficient to pay all damages for loss of life and bodily injury and is less than $\$ 60$ multi- 
Since the traditional rule makes that section the basis for wrongful death libels of alien ships, their owners cannot limit liability and congressional intent to discriminate against them is fulfilled. ${ }^{11}$

Whether sections one and four are also mutually exclusive when applied to aircraft is unclear. ${ }^{12}$ If they are, the result would be substantially opposed to that obtaining in maritime cases. Specifically, recovery would often be greater from an American airline sued for wrongful death under section one than from a foreign defendant sued for similar negligence under section four. Section one sanctions full compensation for dependents' loss of support, ${ }^{13}$ subject only to

plied by the vessel's tonnage, the owner's liability is increased by a sum up to $\$ 60$ per ton. See GilMrore \& BLACK 717-23.

Prior to the DHSA, foreign shipowners sued in American courts could limit their liability under the American statute. See, e.g., The Titanic, 233 U.S. 718 (1914) (single ship); The Scotland, 105 U.S. 24 (1881) (collision). The concluding portion of $\$ 4$ of the DHSA was enacted to reverse these decisions. "But as the Supreme Court has held that the limited liability statute of the United States applies to foreign ships seeking such limitation of liability in our courts, the committee recommends that the bill be amended by the insertion of a new section, to be numbered section $4 \ldots$. S. REP. No. 216, 66th Cong., 1st Sess. 5 (1919). Congressional reaction to The Titantic is not altogether clear. At a minimum, Congress wanted to assist Americans claiming against foreign vessels by preventing alien shipowners from limiting liability under more favorable American law which, unlike the British Merchant Shipping Act, 1894, 57 \& 58 VIcr. c. 60, § 503, then restricted liability to the ship's value at the voyage's end, i.e., in the case of a sunken ship, virtually nothing. For a comparison of British and American limitation laws at that time, see Gilarore \& BLACK 669. But the Supreme Court's classification of limitation statutes as "procedural" meant that, absent recourse to American limitation law, foreign shipowners would not be able to limit at all. Legislative history does not reveal whether Congress was fully aware of these implications of $\S 4$; nor whether Congress intended to proscribe limitation by the owners of alien vessels under any statute, domestic or foreign, irrespective of Supreme Court characterization of limitation law.

11. See note 10 supra. On the other hand, if The Scotland rule is accepted, see note 8 supra, suit against a foreign shipowner for death due to collision must be brought under $\S 1$ of the DHSA, thus enabling the foreign shipowner to limit his liability under American law. This result would defeat congressional intent to preclude a foreign shipowner from taking advantage of the American limitation act. See S. REP. No. 216, 66th Cong., 1st Sess. 5 (1919), quoted note 10 supra.

12. Until Noel v. Linea Aeropostal Venezolana, 247 F.2d 677 (2d Cir.), cert. denied, 355 U.S. 907 (1957), and Fernandez v. Linea Aeropostal Venezolana, 156 F. Supp. 94 (S.D.N.Y. 1957), both arising out of the same crash, all suits under the DHSA for wrongful death in planes involved American carriers. Noel, dismissing an action brought at law, did not decide which section of the DHSA was applicable. For discussion of the decision of the Fernandez court, see notes $21-28$ infra and accompanying text.

13. This is accomplished through a provision in \$ 2, 41. STAT. 537 (1920), 46 U.S.C. \$ 762 (1952), quoted note 3 supra. See, e.g., The S.S. Black Gull, 90 F.2d 619 (2d Cir.), cert. dentied, 302 U.S. 728 (1937) (recovery for death under DHSA gauged by reasonable expectation of pecuniary benefits which would have followed from continued life of decedent) ; The City of Rome, 48 F.2d 333 (S.D.N.Y. 1930) (damages for death on the high seas must take account of deceased's age, earning capacity, health and prospects of advancement, as well as the ages of surviving beneficiaries and the extent of decedent's contribution to their support). See also 2 HARPER \& JAMres, TorTs 1329-32 (1956) (discussing computation for loss of support).

For discussion of the average recovery for pecuniary loss of support, see note 20 infra. 
a possible Warsaw Convention limitation of $\$ 8,000 .{ }^{14}$ In contrast, if death occurs aboard a foreign plane whose flag country is one of the twenty-eight not adhering to the Convention, the law of the flag-which would be "substantive" for purposes of section four ${ }^{15}$ — would ordinarily afford smaller damages than those permitted by the Convention. ${ }^{16}$ Even if the foreign-flag nation

14. Convention for the Unification of Certain Rules Relating to International Transport by Air, Oct. 12, 1929, art. 22, 49 Stat. 3000, T.S. No. 876 (effective June 27, 1934), permits an adherent's carrier to limit liability for negligent loss of life occurring in international carriage. The carrier is presumed negligent and must prove freedom from fault. Art. 17. See note 56 infra. Liability is unlimited if claimant proves the carrier's wilful misconduct. Art. 25.

International carriage is defined as the transportation of passengers aboard the airplane of an adherent nation whenever the place of departure and the place of arrival designated on the passenger's ticket are situated within the territory of two parties to the Convention. Art. 1. See Grey v. American Airlines, Inc., 95 F. Supp. 756 (S.D.N.Y. 1950). The Convention also applies to flights between points of departure and destination situated within the territory of a single adherent if there is an agreed stopping place within another state not a party to the Convention. Art. 1. See Garcia v. Pan Am. Airways, Inc., 269 App. Div. 287, 55 N.Y.S.2d 317 (2d Dep't 1945), aff'd, 295 N.Y. 852, 67 N.E.2d 257, cert. denied, 329 U.S. 741 (1946). Carriage by successive airlines is deemed a single operation providing the parties so intended. See Wyman v. Pan Am. Airways, Inc., 181 Misc. 963, 43 N.Y.S.2d 420 (Sup. Ct. 1943) (Warsaw Convention applied to flights by successive carriers from San Francisco to Hong Kong; plane lost on leg of the flight between Guam and Manila, both within jurisdiction of the United States).

The Protocol signed at the Hague on September 28, 1955, text reproduced in $22 \mathrm{~J}$. AIR L. \& CoM. 422 (1955), increased the limited liability of art. 22 to $\$ 16,000$. However, as of July 16, 1958, the Protocol has not been submitted to the Senate for its advice and consent, and of the thirty ratifications necessary to bring the Protocol into force, only nine have been deposited. See Letter from Charles I. Bevans, Assistant Legal Adviser, Department of State, to the Yale Law Journal, July 16, 1958, on file in Yale Law Library.

15. American courts will enforce limitation upon compensation contained in foreign wrongful death statutes. Such limitations are considered integral to the cause of action and thus "substantive." See, e.g., Slater v. Mexican Nat'1 R.R., 194 U.S. 120 (1904); Northern Pac. R.R. v. Babcock, 154 U.S. 190 (1894) ; Loucks v. Standard Oil Co., 224 N.Y. 99, 120 N.E. 198 (1918). See also Restatenent, Confuicts \& 412; 2 HaRper \& JAMIES, TORTS 1696 (1956).

16. E.g., Costa Rica ( $\$ 3,562$ in case of negligence, unlimited in case of wilful misconduct) ; Guatemala (no higher than $\$ 5,000$ ) ; Honduras (absolute liability but recovery limited to $\$ 5,000$ ) ; Uruguay (liability for negligence may be limited to amount of insurance, unlimited in case of wilful misconduct). International Crvil Aviation Organization Legal Commitree, Documents of the Ninte Session (Doc. 7450-LC/136, 1954) (hereinafter cited as ICAO Documents).

The following nations do not adhere to the Warsaw Convention:

$\begin{array}{llll}\text { Afghanistan } & \text { Cuba } & \text { Iraq } & \text { Siam } \\ \text { Albania } & \text { Dominican } & \text { Japan } & \text { Syria } \\ \text { Austria } & \text { Republic } & \text { Lebanon } & \text { Turkey } \\ \text { Bolivia } & \text { Ecuador } & \text { Nicaragua } & \text { Uruguay } \\ \text { Chile } & \text { El Salvador } & \text { Panama } & \text { Yemen } \\ \text { China } & \text { Guatemala } & \text { Paraguay } & \\ \text { Colombia } & \text { Honduras } & \text { Peru } & \\ \text { Costa Rica } & \text { Iran } & \text { Saudi Arabia } & \\ \text { Bundy, Preparation } & \text { of Airline Tort Cases, 9 Syracuse L. REv. 218, } 219 \text { n.10 (1958). }\end{array}$


were an adherent to (and decedent's flight were covered by) the Convention, recovery could be less than $\$ 8,000$, for many countries require that wrongful death awards be reduced by the amount of any insurance benefits or inheritance received on account of the death in question. ${ }^{17}$ Moreover, a trip which is not international or not scheduled to begin and end within Warsaw countries or not on a Warsaw-nation plane, is beyond the coverage of the Convention ; ${ }^{18}$ hence, recovery becomes entirely contingent on the flag nation's domestic air legislation. ${ }^{19}$ In most cases, this legislation imposes restrictions which reduce damages below those accorded in comparable section one suits. ${ }^{20}$ Consequently, interpretation of sections one and four as exclusive aviation remedies would relegate section four claimants to the generally lower recovery authorized by foreign law.

In Fernandez v. Linea Aeropostal Venezolana, ${ }^{21}$ a federal district court ruled for the first time on whether section four must govern suit for wrongful

17. The Convention leaves to applicable law the questions of "who are the persons who have the right to bring suit and what are their respective rights." Art. 24(2). This clause is interpreted as leaving the question of damages to applicable law. Drion, LIMITAtion of Liabiuities in International Air LAw 125-26 (1954) (hereinafter cited as Drton). Cf. Goedhuts, Natronal Airlegislations and the Warsaw Convention 266-72 (1937).

Insurance collected by claimants reduces the airline's liability by that amount in, e.g., India and The Netherlands, Drion $126 \mathrm{n.4}$, and possibly England, MCNAIR, LAw of THE AIr 216 (2d ed. 1953). These foreign laws have been sharply criticized on the ground that to penalize dependents of an insured person for his prudence in insuring his life is "contrary to the principles of justice." Id. at 217. Inheritance received by claimants from the estate of the victim is deducted by most foreign nations. DRION 126-27.

If foreign law requires periodic computation of damages, American claimants may find themselves forced to sue in foreign courts. Slater v. Mexican Nat'1 R.R., 194 U.S. 120, 128-29 (1904) (because Mexican law fixed compensation periodically in order to reflect changes in claimant's financial circumstances, American courts cannot award lump sum damages, nor should they try to determine damages periodically).

For differences in standing to sue between American and foreign law, see note $\mathbf{5 2}$ infra.

18. For discussion of which flights are covered by the Warsaw Convention, see note 14 supra. See also note 16 supra for a list of nonadherent nations.

19. See note 15 supra.

20. E.g., Belgium (maximum recovery for negligence or wilful misconduct, $\$ 5,000$ ); Brazil (same, $\$ 5,405$ ) ; Denmark (same, $\$ 2,645$ ) ; Luxemburg (same, $\$ 7,500$ ); Netherlands (same, $\$ 3,289$ ); New Zealand (same, $\$ 13,964$ ); Sweden (same, $\$ 3,509$ ); Greece (incorporating the Warsaw Convention limitations, $\$ 8,000$ for negligence, no limitation if wilful misconduct); Mexico (same, $\$ 8,760$ ); Switzerland (limitation by contract). ICAO Documents 221-27. The Venezuelan limit is $\$ 6,000$. Comment, 10 Miami L.Q. 515, 519 (1956).

By way of comparison, the recovery for pecuniary loss of support paid in 1952 under the Federal Employee's Compensation Act, 39 Stat. 742 (1916), as amended, 5 U.S.C. $\S \$ 751-\$ 01$ (1952), averaged $\$ 34,600$ for widows without children (nine cases) and $\$ 45,564$ for widows with children (three cases). Calculated from ICAO DocunENTs 198, but excluding eight fatalities in which recovery was limited by state death statutes.

21. 156 F. Supp. 94 (S.D.N.Y. 1957), 71 HARv. L. REv. 1152 (1958). 
death aboard a foreign airplane and thus deny dependents the American measure of damages. Decedent's administrator, bringing libel for the death of an American citizen on a Venezuelan plane, alleged his standing to sue under section one of the DHSA. ${ }^{22}$ Respondent moved to dismiss on the ground that section four alone was applicable. Denying the motion, the court held that, even though section four preserved any Venezuelan right of recovery, libelant had an additional remedy under section one. ${ }^{23}$ On the grounds that the language of section one purports to apply "whenever death occurs on the high seas" and that recovery against an alien ship or airplane would be impossible under section four if the flag law provided no remedy for wrongful death, the court concluded that Congress meant section one to grant a cause of action against all foreign vessels. ${ }^{24}$ The decision nonetheless did not formally depart from the doctrine that American substantive law cannot determine cases arising aboard foreign vessels on the high seas. ${ }^{25}$ Instead, section one was read to accord libelants a "procedural" "power" enabling them to maintain actions for wrongful death in an American forum. ${ }^{26}$ The court said, however, that the right to sue might arise only if death resulted from actionable negligence under the law of the flag, because section one liability attaches solely to those who "would have been liable if death had not ensued." 27 Thus, the decision presumably means that, given a foreign cause of action for negligence prior to

22. The opinion does not indicate, and the court may not have been aware, that decedent was an American citizen. Letter from H. L. Brinsmade, Proctor for Respondent, to the Yale Law Journal, April 8, 1958, on file in Yale Law Library. Since the victim was a stewardess, $156 \mathrm{~F}$. Supp. at 95, suit for her death was not subject to the limited recovery of the Warsaw Convention which applies only to carriage of persons "for hire" or gratuitously, art. 1. Thus, recovery for her death might be limited by Venezuelan domestic legislation even though Venezuela adhered to the Convention. See note 34 infra.

Although plaintiff alleged a cause of action under all sections of the DHSA, $156 \mathrm{~F}$. Supp. at 95, suit was probably based on $\$ 1$ since libelant pleaded an additional cause of action under Venezuelan law, id. at 98. See 71 HARv. L. REv. 1152 (1958).

23. 156 F. Supp. at 96 .

24. Ibid.

25. See note 6 supra.

26. 156 F. Supp. at 97. Cf. Hohfeld, Fundanental Legal Conceptions as Applied in Judicial Reason, 26 Y ALE L.J. 710 (1917).

27. 41 Stat. 537 (1920), 46 U.S.C. $\$ 761$ (1952), quoted in full note 3 supra. "Thus the liability for an accident causing death would be dependent upon the law of the place where the accident happened-and if it happened on a foreign ship it might well be dependent upon the law which would be applicable to that ship. The right of action for negligence would depend upon the law of the place of accident, but the 'power' to maintain the action would not be dependent upon the locus of the accident but rather upon the forum which exercised that power." 156 F. Supp. at 97.

Nonetheless, the court, on its own theory, should have dismissed the action with leave to amend, on the ground that Venezuelan law necessary to establish a right of action for negligence was not pleaded. An independent cause of action based on Venezuelan law was dismissed with leave to amend because of failure to plead foreign law with sufficient particularity. Id. at 98. See 71 HARv. L. REv. 1152 (1958). 
death, courts will refer to the DHSA to establish capacity to sue, the period during which an action must be brought and awardable damages. ${ }^{28}$

The Fernandez court's denomination of a wrongful death statute as "procedural" is both opposed to recognized doctrine ${ }^{29}$ and conducive to forum shopping, for the decision evidently views legal capacity, statutes of limitation and recoverable damages as questions of local practice rather than integral parts of the law conferring the cause of action. ${ }^{30}$ Moreover, the decisioncouched in terms applying with equal force to ships and planes-ignores congressional intent by characterizing section one as the procedural adjunct of a right to sue found in foreign law. ${ }^{31}$ Until Fernandez, case law had conformed with the congressional design to create in section one a cause of action limited to wrongful death aboard American ships;" the "all-comprehending words" of that section were thus judicially accommodated to the high-seas legislation of other nations. ${ }^{33}$ Possibly, the Fernandez court felt driven to its break with precedent by a desire to allow claimant section one recovery instead of the

28. Limitations upon a "right" are considered "substantive," but limitations upon a "remedy," like the remedy itself, are held "procedural," and determined by the law of the forum. See, e.g., Black Diamond S.S. Corp. v. Robert Stewart \& Sons, Ltd., 336 U.S. 386, 395-96 (1949); The Titanic, 233 U.S. 718, 732-33 (1914).

29. Wrongful death statutes and their limitations on who may bring an action, the period during which suit must be commenced, and the amount of damages and their distribution, are uniformly considered "substantive." See Restatement, Conflicts \$\$ 39197; Goodrich, Conflict of Laws 294-303 (3d ed. 1949) ; Hancock, Torts in the Conflyct of Laws 244-51 (1942); 2 Harper \& JaMres, Torts 1694-97 (1956); Stumberrg, Conflict of Laws 191-97 (2d ed. 1951) ; Tiffany, Deate by Wrongful Act (2d ed. 1913) ; Rose, Foreign Enforcement of Actions for Wrongful Death, 33 MICH. L. REv. 545 (1935) ; Schumacher, Rights of Action Under Death and Survival Statutes, 23 MrcH. L. REv. 114 (1924).

30. See note 28 supra.

31. "From a review of authorities, it is not believed that the Congress has the power to create a substantive right of action to recover damages against foreigners and their vessels for wrongful death on the high seas. The committee concludes that this bill (S. 2085) is particularly designed to provide a law of the forum for American courts in this connection, and a law of the flag for American vessels. But it is clear from the authorities than an action will lie in the United States courts where the statute of the foreign country where the vessel belongs grants a right of action for death by negligence." S. REP. No. 216, 66th Cong., 1st Sess. 4-5 (1919). See also Magruder \& Grout, Wrongful Death Within the Admiralty Jurisdiction, 35 YALE L.J. 395, 426 (1926).

32. See notes 6,8 supra.

33. In Lauritzen v. Larsen, 345 U.S. 571 (1953), the Court refused to extend the Jones Act, 41 StAT. 1007 (1920), 46 U.S.C. $\S 688$ (1952), purporting to apply to "any seaman," to a Danish sailor injured aboard a Danish ship in foreign waters. Even though Congress used "all-comprehending words," the Court said that, in the absence of explicit congressional authority, American statutes should not be construed to apply to areas and transactions which prevalent doctrines of international law leave to the law of other nations. 345 U.S. at 577-78. Cf. Murray v. Schooner Charming Betsy, 6 U.S. (2 Cranch) 64, 118 (1804) (act of Congress ought never to be construed to violate the law of nations if any other possible construction remains). 
lesser remedy available under Venezuelan law and section four. ${ }^{34}$ The rationale chosen to overcome the dichotomy between sections one and four may have been unnecessary, however, for the court rested its reasoning on an unarticulated assumption required neither by established authority nor congressional history-that identical criteria determine the reach of section one for both ships and aircraft. ${ }^{35}$ In any event, the court chose between federal and foreign remedies without discussing the relative merits of either in the context of an American death aboard a Venezuelan plane.

In the leading case of Lauritzen $v$. Larsen, the Supreme Court said that conflict of laws in admiralty tort cases should be resolved by weighing the significant points of contact which a given case has with various nations and their competing laws. ${ }^{36}$ Because every country may have an interest in redress

34. The court's reasoning is based upon the possibility that Venezuelan law provides a cause of action for negligence, but not for wrongful death. It is not clear whether the court knew that Venezuela permits recovery for wrongful death under Código Penal VeNEZOLANo arts. 113, 123, 411 (Silva ed. 1943), since the court dismissed a separate cause of action based upon Venezuelan law for failure to plead with sufficient particularity. See note 27 supra. Although Venezuelan law allows recovery for air accidents, the maximum award is fifteen thousand bolivars $(\$ 4,800)$ under its workmen's compensation statutes, 1955 LAwyers DireCtoRy 2194, or $\$ 6,000$ under its domestic air legislation, see note 20 supra. Even if the court knew that recovery was possible under Venezuelan law, its holding allows claimants to escape these limitations. See note $2 S$ supra.

35. Both the report of the Senate Committee on the Judiciary, S. REp. No. 216, 66th Cong., 1st Sess. 4 (1919), quoted note 31 supra, and congressional debates on the DHSA, 59 Cong. Rec. 4482-86 (1920), refer only to ships. Congress probably did not consider the question of the DHSA's relation to airplanes. See Comment, 55 Colun. L. Rev. 907, 916, 920 (1955). But cf. Choy v. Pan-Am. Airways Co., 1941 Am. Mar. Cas. 483, 485 (S.D.N.Y.).

Since Fernandez is the first case to consider which section of the DHSA applies to foreign planes, nothing in prior decisions indicates that the exclusive interpretation of $\$ \$ 1$ and 4 developed for ships must be extended to planes. Indeed, for other purposes of maritime law, planes have not been analogized to ships. See note 44 infra.

36. 345 U.S. 571,582 (1953).

In Lauritzen, a Danish seaman injured aboard a Danish owned and registered ressel attempted to recover in a federal court under the American Jones Act for injury occurring in Cuban waters. His articles, which specified that Danish law would govern the rights of crewmen, were signed in New York, where the plaintiff temporarily resided. The voyage was to begin and end in the United States. Since all possible contacts were foreign except temporary residence and the place where the shipping articles were signed, the Court addressed itself to one of the weakest possible cases for the application of American law; and the myriad of other possible combinations of American and foreign law were left unresolved. See GILMORE \& Black 387.

The contacts considered by the Court were the flag, the place of injury, allegiance of the victim, allegiance of the shipowner, place of contract and the forum. The Court held that the choice of forum does not justify application of the lex fori if it has no other contact with the transaction. 345 U.S. at 590-91. Nor was the place of a seaman's employment contract accorded much significance in the choice of tort law. Id. at 588-89. The Court indicated that the law of the flag is a weightier contact than the law of the place of injury, though it did not have to consider the lex loci delicti, since neither party alleged a Cuban cause of action. Id. at 584-86. The Court did not decide the importance 
for its residents suffering injury or loss of support, the Court indicated that the citizenship and domicile of the victim should be considered along with the ship's flag in choosing the proper legal remedy. ${ }^{37}$ The case did not decide, however, whether flag law is controlling when an American is injured on a foreign ship. ${ }^{38}$

Even if the law of the flag always governs maritime torts on the high seas, analogy does not require that the same rule obtain when suit is brought for wrongful death aboard an airplane. The importance attached to a vessel's flag springs from admiralty doctrine regarding the ship as floating territory of the nation of registration. ${ }^{39}$ Expedient in an age when ships were out of port for

of flag as against ownership, since both were Danish. Id. at 587-88. For a discussion of the significance of the victim's nationality, see note 38 infra; see also GirMore \& BLACK 386-90; Comment, 53 Mick. L. Rev. 100 (1954).

37. 345 U.S. at 586 .

38. Since the ship's flag and the victim's nationality coincided, the Court declined to weigh the relative importance of the flag and the injured's allegiance or domicile. Id. at 587.

To demonstrate that nationality is a proper contact for the choice of law, the Lauritzen Court cited cases involving American citizens and permanent residents injured aboard foreign ships in American waters. Uravic v. F. Jarka Co., 282 U.S. 234 (1931) (longshoreman, citizen) ; Gambera v. Bergoty, 132 F.2d 414 (2d Cir. 1942) (seaman with first citizenship papers); Shorter v. Bermuda \& West Indies S.S. Co., 57 F.2d 313 (S.D.N.Y. 1932) (seaman, citizen). Hence, Lauritzen could be interpreted as indicating that the law of the flag is weightier than the victim's nationality or domicile unless the place of injury and the injured's allegiance or domicile coincide.

Prior to Lauritzen, Jones Act damages were denied a British seaman who was a permanent resident of the United States and died aboard a British vessel on the high seas. O'Neil v. Cunard White Star, Ltd., 160 F.2d 446 (2d Cir. 1947). A post-Lauritzen decision, Smith v. Furness, Withy \& Co., 119 F. Supp. 369 (S.D.N.Y. 1953), reasoning that Lauritzen did not overrule O'Neil, denied extension of the Jones Act to a British national injured on a British ship on the high seas, although he had resided in the United States for two years and had applied for his first citizenship papers. The law of the flag, rather than the nationality of the injured, was also applied in Samad v. The Etivebank, 134 F. Supp. 530 (E.D. Va. 1955) (Pakistani injured on a British ship in American waters).

If Lauritsen is interpreted to mean that nationality or domicile govern only when they coincide with the place of injury, American nationals and permanent residents injured in American waters will benefit from the application of American law. On the high seas, however, the law of the flag would still govern. See Comment, 53 Mrch. L. Rev. 100, 10809 (1954). One treatise, however, makes no distinction between injury in American waters and on the high seas, maintaining that after Lauritzen courts may and perhaps must apply American law to citizens and permanent residents. GrLmoRe \& BLAcK 388 n.409. This interpretation seems inappropriate in actions for shipboard death brought under the DHSA, because dependents of an American victim would have to sue a foreign ship under $\S 1$ and thus entitle the foreign shipowner to avail himself of the American limitation of shipowner's liability statute. This result would violate congressional intent to deny a foreign shipowner the benefit of limiting his liability under American law. See note 10 supra.

39. See, e.g., United States v. Flores, 289 U.S. 137 (1933) (criminal jurisdiction, although not extraterritorial, extends to an American ship in foreign waters, since vessel is part of the territory whose flag it flies) ; Carpo v. Kelly, 83 U.S. (16 Wall.) 610 (1872) 
months and away from home for years, ${ }^{40}$ the doctrine loses its relevance under conditions of modern air travel involving only brief connection between plane and passenger. ${ }^{41}$ The doctrine's pertinence is further reduced by the fact that the law of the vessel's flag establishes liability for shipboard injury in foreign waters, ${ }^{42}$ while the law of the place below governs torts occurring on aircraft over land or territorial sea. ${ }^{43}$ Furthermore, a plane crash into the ocean has

(because a vessel owned by a Massachusetts resident is part of the territory of that state, an assignment in Massachusetts conveying the ship while she was at sea is preferred to a subsequent attachment in port) ; The Case of the S.S. "Lotus," P.C.I.J., Ser. A, No. 10 (1927) (injury to passengers on a Turkish ship is like an injury on that nation's territory for purposes of criminal jurisdiction).

Courts have refused, however, to extend the doctrine to its logical conclusion. See, e.g., Scharrenberg v. Dollar S.S. Co., 245 U.S. 122 (1917) (aliens working on American ship cannot be deemed working on American territory); Wong Ock Jee v. Weedin, 24 F.2d 962 (9th Cir. 1928) (an alien does not enter the United States when he boards an American vesse1) ; Lam Mow v. Nagle, 24 F.2d 316 (9th Cir. 1928) (birth aboard American vessel on the high seas is not equivalent to being born in the United States) ; Rex v. Gordon-Finlayson, [1941] 1 K.B. 171 (ship not analogized to territory for purpose of criminal procedure). For criticism of the floating-territory doctrine, see Hrgains \& Corourbos, InTERNATIONAL LAW OF The SEA 212-14 (3d ed. 1954).

40. The floating-territory doctrine can be traced back to 1752 . Hrgarns \& Colombos, op. cit. supra note 39, at 212-13. By 1879, Secretary of State Everett was able to state that the principle is well recognized that a merchant ship on the high seas is part of the territory of the nation to which it belongs. 1 MOORE, Digest of International LAw 933 (1906).

41. "As has been noted, this application of the 'law of the flag' has by now become deeply and ineradicably ingrained in our law, and ships have even acquired a kind of 'legal personality.' But these considerations cannot be said to apply to aircraft to anything like the same extent. The essence of carriage by air as compared with carriage by sea is speed and shortness of duration, and aircraft do not predominantly operate over the high seas .... There is therefore, it is submitted, much less connection between persons and goods aboard an aircraft and the country of its registration than in the case of a ship." MCNAIR, LAw of THE AIr 110 (2d ed, 1953). See also Honig, Legal Status of Aircraft 98-99 (1956) (the absence of any prolonged connection between the air carrier and its passengers renders impossible any analogy between air and maritime law).

42. See, e.g., Markakis v. Liberian S/S The Mparmpa Christos, 161 F. Supp. 487, 504 (S.D.N.Y. 1958) (law of the flag applies to injury of Greek national aboard a vessel registered in Liberia and owned by a Panamanian corporation; libelant engaged in Greece, signed articles in Germany with injury occurring in American waters); Samad v. The Etivebank, 134 F. Supp. 530 (E.D. Va. 1955) (law of British vessel applied to Pakistani who signed in India and injured in American waters). But see note 38 supra for cases holding American law applicable to American domiciliaries injured aboard foreign ships in American waters.

43. Death due to air crashes in foreign territories are governed by the death statute of the locus delicti. See, e.g., Komlos v. Compagnie Nationale Air France, 209 F.2d 436 (2d Cir. 1953), cert. denied, 348 U.S. 820 (1954) (Portugal); Werkley v. Koninklijke Luchtvaart Maatschappij N.V., 111 F. Supp. 300 (S.D.N.Y. 1951) (India). According to the Convention on International Civil Aviation, Dec. 7, 1944, art. 2, 61 STAT. 1180, T.I.A.S. No. 1591 (effective April 4, 1947), the term "territory" comprises both land areas and territorial waters adjacent thereto. Cf. Hughes, Airspace Sovereignty Over Certain International Waterways, 19 J. AIr L. \& Con. 144 (1952). National claims to a "marginal sea" 
not been analogized to shipwreck in order to employ any other admiralty doctrines (such as salvage). ${ }^{44}$ Consistency therefore does not demand that the law of the plane's flag always apply. And since the federal statute sanctioning limitation of shipowner's liability does not cover airlines, ${ }^{45}$ the congressional policy of discriminating against owners of alien ships would not be frustrated by awarding section one damages when an American is killed aboard a foreign plane. ${ }^{46}$

Free to establish a meaningful conflicts standard for selecting applicable tort law in aviation DHSA cases, courts should consider decedent's domicile the critical determinant. ${ }^{47}$ This central contact point for all claims resulting

may extend territorial jurisdiction to large parts of the airspace over the high seas. MrcDougal \& Burke, Crisis in the Law of the Sea: Community Perspective Versts National Egaism, 67 YALE L.J. 539, 579 (1958) ; cf. Hilbert, Jurisdiction in High Seas Criminal Casis-Part II, 19 J. ArR L. \& CoMr. 25, 35-37 (1952).

44. E.g., Foss v. The Crawford Bros. No. 2, 215 Fed. 269 (W.D. Wash. 1914) (airplane not subject to maritime lien for salvage and repair); see also Air Commerce Act $\S 7$ (a), 44 STAT. 572 (1926), as amended, 49 U.S.C. $\$ 177$ (a) (1952) ("the navigation and shipping laws of the United States ... shall not be construed to apply to seaplanes or other aircraft ..."); Stickrod v. Pan Am. Airways Co., 1941 U.S. Av. R. 69 (S.D. N.Y.) (crew of plane lost at sea not "seamen" within Jones Act); Noakes v. Imperial Airways, Ltd., 29 F. Supp. 412 (S.D.N.Y. 1939) (owner of seaplane that crashed into the high seas may not limit his liability under the limitation of shipowner's liability statute) ; Cooper, Legal Status of Aircrafr 5-9 (1949) ; Comment, 55 Colums. L. Rev. 907, 919 (1955). International law also distinguishes between ships and planes. Unlike ships, planes do not have the right of innocent passage over territorial and marginal waters. Hilbert, supra note 43, at 37; McDougal \& Burke, supra note 43, at 579.

In the salvage of seaplanes, however, admiralty principles have been applied. Lambros Seaplane Base, Inc. v. The Batory, 215 F.2d 228 (2d Cir. 1954).

45. Noakes v. Imperial Airways, Ltd., supra note 44 ; Dollins v. Pan-Am. Grace Airways, Inc., 27 F. Supp. 487 (S.D.N.Y. 1939).

46. Congressional intent to deny owners of foreign ships the benefit of the American limitation of shipowner's liability statute seems to require application of the law of the flag in suits for wrongful death aboard ships. See notes 11,38 supra. On the other hand, the absence of any congressional design to discriminate against owners of foreign airlines allows courts to apply American law to wrongful death aboard planes when such law has a meaningful contact with the accident. Despite its broad language, $\S 1$ of the DHSA, quoted note 3 supra, may be applied only when American law finds a significant contact with the accident. See Lauritzen v. Larsen, 345 U.S. 571 (1953) (conflict of laws in admiralty tort cases determined according to the contacts which the conficting laws have with the transaction, despite comprehensive legislative terms).

47. Decedent's domicile, rather than the place of injury, was chosen as determining survival action in, e.g., Grant v. McAuliffe, 41 Cal. 2d 859, 264 P.2d 944 (1953) (alternate ground) (decedent tortfeasor and claimants domiciled in California, injury in Arizona). See also Stumberg, Conflict of LAws 206 (2d ed. 1951) (survival of actions

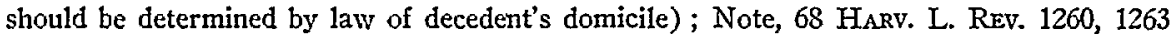
(1955) (same). Also, in the determination of the applicable workmen's compensation acts, "the domicile of the worker now emerges as the most important single contact." Storke \& Sears, Recitracal Exemption Provisions of Workmen's Compensation Acts, 67 YALE L.J. 982, 989 (1958). But see Ormsby v. Chase, 290 U.S. 387 (1933) (place of injury governs survival action for wrongful death). 
from a wrongful death would direct tribunals to the tort law of the jurisdiction governing the deceased's estate ${ }^{48}$ which, in most cases, would also be the jurisdiction in which the claimants reside. ${ }^{49}$ Thus, section one damages would be awarded irrespective of the flag of the carrying plane whenever an American domiciliary was wrongfully killed on the high seas. Since the victim's dependents would probably also be American residents, section one recovery should reflect their standard of living more accurately than an award under foreign statutes geared to the economic and social norms of other countries. ${ }^{50}$ Specifically, American claimants would frequently avoid the deduction of insurance benefits or inheritance and would escape other rigid limitations which the domestic legislation of numerous foreign nations imposes on recovery from airlines. ${ }^{51}$ Conversely, were federal courts consistently to employ the wrongful death statute of a foreign decedent's nation of domicile, the fortuity of the plane's flag would cease to be controlling. As a result, section four would govern suit on account of a nonresident killed on an American or a foreign plane, and the positive law of the passenger's community-modified by the Warsaw Convention where applicable-would establish standing to sue and the measure of relief. ${ }^{52}$

48. Upon the death of an owner of property, succession to his moveables, whether testate or intestate, is, in the absence of statute, controlled by the law of his domicile at the time of death. See Restatement, Conflicts $\$ \S 470,522$; Stumberg, op. cit. supra note 47 , at 437 . Succession to realty, however, is governed by the law of the situs. Ibid.

49. Decedent's family is likely to be located in his state of domicile. Even if the dependents' domicile is other than that of the deceased, their expectations as to compensation for wrongful death are likely to be geared to the estate devolving upon them, and these expectations will be subject to the law of decedent's domicile which governs his estate. Cf. Ibid.; Note, 68 Harv. L. Rev. 1260, 1264 (1955).

50. "If there is any field in which unification of the law on a world wide basis would be inappropriate, it is in the field of the amount of damages to be paid in case of death or injuries. For in few areas are local views and circumstances of a social and economic character of such importance." Drion 42. Compare the limited recoveries authorized by foreign legislation discussed notes 16, 20 supra, with the average recovery in the United States discussed note 20 supra.

Requiring all carriers to pay $\S 1$ damages might force foreign airlines to take out more liability insurance; but the cost would not be prohibitive. In 1954, an increase of $\$ 8,000$ coverage per passenger cost .006 per passenger mile. Since the average total operating cost is $7 \phi$ per passenger mile, an $\$ 8,000$ increase in coverage per passenger would amount to $\$ 6$ for each $\$ 7,000$ of all operating costs or $.08 \%$. These figures are based on two fatalities per 100,000,000 passenger miles, the accident rate in 1954. See, generally, ICAO Documents 132-33. Extrapolating these figures, an increase of insurance coverage from $\$ 8,000$ to $\$ 40,000$ per passenger over a 3,000 mile trip would cost $72 \xi$.

51. See notes 16-21 supra and accompanying text.

52. Positive law differs with respect not only to damages but also standing to sue. The DHSA allows only dependent relatives to recover for pecuniary loss of support. See Peterson v. United N.Y. Sandy Hook Pilots Ass'n, 17 F. Supp. 676 (E.D.N.Y. 1936) ("pecuniary loss" does not include grief or loss of society and companionship). Other countries, however, authorize the estate or heirs, irrespective of kinship, to sue, and provide compensation for grief. DRION $81 \mathrm{n.1}, 126$. Furthermore, according to information received from members of the ICAO, many nations consider $\$ 8,000$ ample compensation. 
Although protecting the dependents of American domiciliaries against federal court adoption of the comparatively small recoveries authorized by foreign law, the proposed rule could induce forum shopping if other countries applied the law of the flag to aircraft. The probable extent of such forum shopping appears insufficient, however, to preclude unilateral adoption of the domiciliary rule. For example, were federal courts to accept the rule, the death of an American permanent resident on a foreign plane would cause claimants not to sue abroad under the flag law but instead in the United States under section one (if jurisdiction over the airline could be obtained). Yet the federal forum would usually be the one chosen in this case, anyway, since dependents of an American domiciliary would be likely to live in the United States. And in the reverse situation-death of a foreign domiciliary aboard an American plane - suit overseas under flag law (section one) rather than in the United States under the law of domicile (section four) would not ordinarily involve an unnatural choice of forum. . $^{\text {s }}$ Furthermore, in this latter situation, the foreign tribunal looking to American flag law could achieve uniformity by applying American conflicts rules and thus the tort law of decedent's domicile just as a federal court would. ${ }^{54}$ Still a third possibility-foreign domiciliary killed on an alien plane-might invite suit in this country whenever the domicile's wrongful death statute was more favorable than that of the flag. In such a case, dismissal on grounds of forum non conveniens could prevent undue exploitation of an American rule of domicile.55 Finally, to obviate a search by libelants for

ICAO Docunfents 131. Indeed, the domestic legislation of many Warsaw adherents limits recovery far below $\$ 8,000$. See note 20 supra.

In all events, an airline whose nation adheres to the Warsaw Convention may limit liability in case of negligence if the passage at issue is covered by the Convention. See note 14 supra. This Warsaw right should be observed in suits brought against an adherent's airline under $\S 4$ of the DHSA, even though $\S 4$ permits recovery "without abatement in respect to the amount for which recovery is authorized, any statute of the United States to the contrary notwithstanding." 41 STAT. 537 (1920), 46 U.S.C. $\S 764$ (1952). This provision was designed to prevent foreign shipowners from limiting their liability under American law. See note 10 supra. Thus, $\$ 4$ should not be construed to prevent airlines from limiting their liability when the Warsaw Convention applies. "[A]n act of Congress ought never to be construed to violate the law of nations [here, the Warsaw Convention] if any other possible construction remains." Murray v. Schooner Charming Betsy, 6 U.S. (2 Cranch) 64, 118 (1804). See also Whitney v. Robertson, 124 U.S. 190, 194 (18S8) (courts will always endeavor to construe legislation and treaty relating to the same subject so as to give effect to both).

53. Since the dependents of the foreign victim are likely to live abroad, they would generally prefer to sue an American line in their own court if they can obtain jurisdiction.

54. British courts, for example, would decide the case as would a federal court by accepting transmission to the tort law of decedent's domicile. See Comment, 31 B.U.L. REv. 69, 71 \& $\mathrm{n} .11$ (1951) (collecting cases on transmission in British courts).

55. Admiralty courts exercise their discretion in refusing to entertain suits between aliens on grounds of inconvenience or harassment by libelant. See, e.g., Canada Malting Co. v. Patterson S.S., Ltd., 285 U.S. 413 (1932) (collision between Canadian ships in American waters) ; Nakken v. Fearnley \& Eger, 137 F. Supp. 288 (S.D.N.Y. 1955) (foreign seamen injured aboard a foreign vessel in American waters); Bickel, The Doctrine 
lenient negligence standards, the law of the flag could remain the source of the definition of conduct by which airlines would be measured in all jurisdictions. ${ }^{56}$

The proposed criteria for choosing the law governing negligence and recoverable damages would allow equitable treatment of all airlines without defeating the probable needs and expectations of claimants. Thus, in Fernan$\mathrm{dez}$, if decedent was domiciled in Venezuela, application of the foreign remedy would have been consistent with the legal framework regulating the relationship of claimants with the estate and thus most intimately connected with their expectancies. ${ }^{57} \mathrm{Had}$ the deceased been a permanent resident of this country, however, her dependents would have been more likely to require and expect

of Fortm Non Conveniens as Applied in the Federal Courts in Matters of Admiralty, 35 CoRnell L.Q. 12 (1949); Comment, 31 Texas L. Rev. 889 (1953).

56. Each nation regulates the airworthiness of its planes and competency of its crews, subject to the minimum standards set by the ICAO. See Convention on International Civil Aviation, Dec. 7, 1944, arts. 31, 37, 61 Stat. 1180, T.I.A.S. No. 1591 (effective Apri1 $4,1947)$. The breach of these regulations may give rise to liability or to evidence of negligence according to the law of the place (here, the law of the flag). RESTATEMENT, ConFLICTS $\S 381$. Whether the breach constitutes negligence or wilful misconduct is also governed by the law of the place (flag). Id. $\$ 380(2)$, comment $a$.

Some countries, e.g., Costa Rica, Czechoslovakia and the U.S.S.R., impose absolute liability for plane accidents. ICAO Documents $222,227,229$. Most nations, including the United States, impose liability only if respondent was at fault, but favor claimants with a presumption of negligence. Id. at 221-31; Trihey v. Transocean Air Lines, Inc., 26 U.S.L. WeEk 2621 (9th Cir. May 5, 1958) (suits under $\$ 1$ of the DHSA because of plane accident give rise to a presumption of liability). If death accurs on a Warsaw Convention flight, art. 17 of the Convention imposes a presumption of negligence. S. ExEc. Doc. No. G., 73d Cong., 2d Sess. 3 (1934); Wyman v. Pan Am. Airways, Inc., 181 Misc. 963, 43 N.Y.S.2d 420 (Sup. Ct. 1943) (summary judgment for plaintiff despite absence of proof of negligence, as defendant unable to rebut presumption). See also Noel v. Linea Aeropostal Venezolana, 247 F.2d 677 (2d Cir.), cert. denied, 355 U.S. 907 (1957) (dictum).

Unlike a presumption of negligence, which is uniformly considered procedural, absolute liability under flag law will be enforced by a court applying the negligence standards of the flag. Restatement, Conflicts \& 595(2). Thus, where domestic air legislation rather than the Warsaw Convention is applicable, foreign law may combine limited recovery with absolute liability. See, e.g., ICAO Documents 229 (Costa Rica, \$3,561) ; Comment, 10 Mrami L.Q. 515, 519 (1956) (Venezuela, \$6,000). In such cases, enforcement of the flag standard of care for death of an American aboard a foreign plane would subject the airline to unlimited recovery under $\$ 1$ of the DHSA and absolute liability under the law of the flag. Conversely, death aboard an American plane of a foreign domiciliary whose law tempers absolute liability with limited recovery, may limit the dependents' possible recovery while enabling the airline to exculpate itself from liability altogether. Consequently, when foreign law combines absolute liability and limited recovery, courts should apply the standard of care contained in decedent's domiciliary law as well as his law's measure of damages. As a result, suit under $\$ 1$-American victim aboard a foreign plane-would be governed by a presumption of liability and recovery based upon pecuniary loss of support; while suit under \$ 4-foreign victim aboard American or foreign plane-would be predicated upon absolute liability and the limited recovery authorized by the victim's domiciliary law.

57. See notes 48-50 supra and accompanying text. 
recovery consonant with American standards. ${ }^{58}$ Moreover, if domicile had been controlling and decedent was an American domiciliary, respondent Venezuelan airline would not have been able to take advantage of its foreign flag to avoid section one recovery. Similarly, the suggested rule would permit United States airlines to pay section four damages if decedent was domiciled in a nation with a more limited remedy. ${ }^{59}$ The rule therefore would end present procedure discriminating in favor of airlines whose flag law requires relatively small tort awards. ${ }^{60}$ Rather, all airlines would compensate for the wrongful death of a given domiciliary at roughly the same rate. Thus, the new rule, while benefiting dependents of American residents killed on foreign planes, would also remove the competitive advantage currently enjoyed by airlines flying the flags of low-recovery jurisdictions. ${ }^{01}$

58. See note 50 supra and accompanying text.

59. See note 52 supra and accompanying text.

60. Cf. Lissitzyn, Public Aid to Major Foreign Airlines-Parts $I$ and II, $18 \mathrm{~J}$. AIR L. \& CoMr. 379 (1951); 19 id. at 38 (1952).

61. Death aboard a plane over land presents dependents of an American victim with the same dangers of limited recovery as under the flag law when a foreign plane crashes into the high seas.

Currently, if the decedent's journey is governed by the Warsaw Convention, the place of injury provides a cause of action for wrongful death, subject to the limitations of the Convention. See Komlos v. Compagnie Nationale Air France, 209 F.2d 436 (2d Cir. 1953), cert. denied, 348 U.S. 820 (1954) (lex loci delicti determines who may bring suit for wrongful death); Werkley v. Koninklijke Luchtvaart Maatschappij N.V., 111 F. Supp. 300 (S.D.N.Y. 1951) (American decedent's estate may not sue since Indian death statute grants compensation only to dependents). Insurance and inheritance deduction will similarly be determined by the law of the place of injury. See note 17 supra. On an overland flight which is not covered by the Convention, the domestic air legislation of the place of injury, with its frequently severe limitations, will govern recovery. See notes 18-20 supra.

The law of the geographical place of accident is an even more irrational basis for recovery than the law of the aircraft's flag. The place of injury is haphazardly chosen by fate as the plane crosses boundaries within hours, if not minutes. And when a plane disappears without a trace, or death occurs in the air, it may be impossible to ascertain where injury occurred. See Comment, 41 CoRnelL L.Q. 243, 252-53, 261-62 (1956). Consequently, as with death aboard an airplane over the high seas, the law of the victim's domicile should furnish the cause of action and determine the amount of recovery for wrongful death over land, subject to applicable Warsaw Convention limitations. In the absence of a federal death statute, the law of the domicile for an American injured on or over land is state law. But since seventeen states limit recovery for wrongful death to an average of $\$ 13,000$, see Orr, The Rio Revision of the Warsaw Convention-Part II, 21 J. AIR L. \& COM. 174, $176 \mathrm{n} .14$ (1954), a uniform federal rule clearly appears desirable, see $i d$. at 181 (suggesting legislation to give a right of action for death of American air passengers in foreign jurisdictions). Cf. Sweeney, Is Special Liability Legislation Essential?, 19 J. AIR L. \& CoMr. 166, 317 (1952) (recommending federal regulation of aircraft liability within the United States). 